\title{
PENGARUH KUALITAS STRATEGI MEMBACA TERHADAP PRESTASI AKADEMIK
}

\author{
Suprihadi dan Muh. Syafei \\ Program Studi Pendidikan Bahasa Inggris \\ Fakultas Keguruan dan Ilmu Pendidikan \\ Universitas Muria Kudus \\ Surel: suprihadi@umk.ac.id Telp: 08562758418
}

Submitted: 2018-09-30

Accepted: 2019-07-02

Published: 2019-08-27

\begin{tabular}{ll}
\hline Keywords: & Abstract \\
\hline Quality of & Students of the English Language Education at the Faculty of Teacher \\
reading & Training and Education of Muria Kudus University as learners and users \\
Strategies, & of English are forced to become independent, effective, efficient and \\
Academic & strategic readers. The purpose of this study is to examine the correlation \\
achievement & between the quality of reading strategies and students academic \\
& achievement. The research subjects consisted of 104 PBI UMK students \\
& from all semesters, who were randomly selected. This was a quantitative \\
& research. The data were collected using a closed questionnaire. The \\
& results showed that there was no correlation between the quality of \\
& reading strategies and academic achievement, in the sense that the quality \\
& of reading strategies had no effect on student academic achievement.
\end{tabular}

\section{PENDAHULUAN}

Sebagai pembelajar dewasa, mahasiswa diharapkan sudah cukup matang untuk berkiprah dalam dunia belajar perguruan tinggi. Salah satu karakteristiknya adalah kemandirian dalam belajar. Untuk mencapai kemandirian tersebut mau tidak mau mereka harus menguasai keterampilan membaca. Mereka harus mampu menjadi pembaca yang baik, yaitu mampu membaca secara efektif dan efisien baik untuk mempelajari sesuatu maupun untuk belajar cara belajar yang baik. Oleh karena itu, membaca harus menjadi menu utama dan aktivitas sehari-hari dalam kehidupan mahasiswa. Seperti dikatakan oleh Ness (dalam Kissau, 2013), keterampilan membaca yang baik sangat penting bagi mahasiswa di abad ke- 21 ini. Jika tidak, kemungkinan besar mereka akan mendapat masalah.

Persyaratan menjadi pembaca yang mandiri, efektif, dan efisien semakin nyata dan dibutuhkan oleh mahasiswa Program Studi Pendidikan Bahasa Inggris Fakultas Keguruan dan Ilmu Pendidikan Universitas Muria Kudus (selanjutnya disebut PBI UMK). Hal ini tidak lain karena peran ganda mereka sebagai pembelajar bahasa sekaligus pengguna bahasa. Oleh karena itu, wajar bila reading ditetapkan sebagai mata kuliah wajib yang diberikan di PBI UMK, yang dalam proses perkuliahannya menuntut mahasiswa mengerjakan tugas-tugas membaca yang memerlukan strategi-strategi yang tepat dan baik kualitasnya. Pertanyaan yang muncul adalah apakah mahasiswa PBI 
Suprihadi dan Muh. Syafei, Pengaruh Kualitas Strategi Membaca ... .

UMK sudah mampu menjadi pembaca yang mandiri, efektif, efisien, dan strategis".

Salah satu defininisi membaca adalah mengidentifikasi kata dan mendapatkan maknanya (Foertsch, 1998).

"sebuah proses aktif (bukan produk, seperti sejarah) tempat pembaca berpindah antara sumber-sumber informasi (apa yang mereka ketahui dan apa yang terdapat dalam teks), mengelaborasi makna dan strategi, mengecek penafsiran mereka (merevisi bila sesuai), dan menggunakan konteks sosial untuk mengarahkan respon mereka"

Dalam definisi tersebut tersirat makna bahwa pembelajar berperan aktif. Ia haruslah seorang pembaca yang strategis dan pengguna strategi yang baik. Pemahaman diperoleh dari interaksi antara pembaca, strategi-strategi yang digunakan, bahan bacaan, dan konteks membaca terjadi.

Untuk menjadi pembaca yang baik, diperlukan strategi pembelajaran yang baik pula. Cohen (1998) mendefinisikan strategi pembelajaran sebagai proses pembelajaran yang secara sadar dipilih oleh pembelajar. Dalam definisinya tersebut ia menekankan pentingnya pilihan karena pilihan itulah yang menjadikan strategi memiliki karakter spesial. Penciri lain yang juga penting adalah keberadaan unsur kesadaran dalam strategi (Cohen, 1998; Chamot, 2005) dan berorientasi tujuan (Chamot, 2005). Elemen kesadaran itulah yang membedakan strategi dari proses-proses lain yang tidak strategis. Dengan menambahkan kata bahasa dalam batasan strategi pembelajaran maka kata strategi pembelajaran bahasa menjadi bermakna proses pembelajaran bahasa yang secara sadar dipilih pembelajar.

Strategi pembelajaran penting dalam pengajaran dan pembelajaran bahasa asing (Chamot, 2005). Dua alasan utama yang ia usulkan yaitu:

1. Dengan mengamati strategi yang digunakan oleh pembelajar bahasa selama proses pembelajaran, kita memperoleh pemahaman tentang proses metakognitif, kognitif, sosial, dan afekif yang ada dalam pembelajaran bahasa

2. Penelitian yang dilakukan oleh Grenfell dan Harris menunjukkan bahwa pembelajar bahasa yang kurang berhasil dapat diajari strategi-strategi baru sehingga membantu mereka menjadi lebih baik

Pembelajaran bahasa dan penggunaan bahasa merupakan dua proses yang berbeda namun tidak dapat dipisahkan satu sama lain, demikian pula strategi-strateginya. Terkait dengan hal tersebut, Cohen (1998) mendefinisikan strategi pembelajaran dan strategi penggunaan bahasa dalam sebuah gagasan, yaitu:

"(those processes which are consciously selected by learners and which may result in action taken to enhance the learning or use of a second or foreign language, through the storage, retention, recall, and application of information about that language.")

('proses-proses yang secara sadar dipilih oleh pembelajar dan yang dapat menghasilkan tindakan yang diambil untuk memperluas pembelajaran atau penggunaan bahasa kedua atau asing melalui penyimpanan, pengendapan, pengeluaran kembali, dan penerapan informasi tentang bahasa yang bersangkutan').

Menurut Barnett (1988), strategi membaca adalah kerja mental yang berlangsung ketika pembaca melakukan pendekatan terhadap teks secara efektif dan berupaya untuk memahami teks yang mereka baca. Strategi membaca mencakup memahami tujuan 
membaca, mengaktifkan latar belakang pengetahuan yang relevan, mencurahkan perhatian pada gagasan utama, mengevaluasi secara kritis, memonitor pemahaman, dan membuat simpulan (Palincsar \& Brown, 1984). Oleh karena itu, penting bahwa dalam rangka meningkatkan tingkat pemahaman membaca, fokus perhatian diletakkan pada pengembangan kesadaran pembaca terhadap strategi membaca.

Pearson dan Gallagher (1983) mencermati bahwa pembaca yang baik adalah pembaca yang memiliki kemampuan lebih dalam merangkum dan menggunakan latar belakang pengetahuan secara efektif. Mereka juga memanfaatkan struktur teks, membuat simpulan-simpulan, menyadari strategi-strategi yang mereka gunakan dan secara umum mereka lebih baik dalam hal memantau dan menyesuaikan strategi-strategi yang mereka gunakan. Dengan kata lain, pembaca yang baik lebih strategis dalam membaca dibanding dengan pembaca yang kurang atau tidak baik. Sementara itu, menurut Hosenfield (1977) seorang pembaca yang baik adalah pembaca yang mencoba mengingat arti bacaan, membaca dalam penggalan-penggalan, mengabaikan kata-kata yang tidak terlalu penting, mencoba menebak arti kata-kata yang tidak dikenal dengan penanda kontekstual, dan memiliki konsep diri yang baik sebagai pembaca.

Dalam sebuah proses membaca terdapat 3 tahapan, yaitu tahap sebelum, selama, dan sesudah membaca. Pada setiap tahap membaca strategi yang diterapkan berfungsi berbeda. Strategi sebelum membaca digunakan untuk merangsang pembaca mengaktifkan pengetahuan yang telah dimilikinya sehingga tercipta kerangka pikir untuk dikaitkan dengan bacaan baru, istilah, gagasan, dan sebagainya. Kerangka pikir tersebut mulai dibentuk bahkan sebelum membaca dimulai, diperkuat saat pembaca berinteraksi dengan bacaan sewaktu proses membaca, dan direfleksi setelah membaca ketika pembaca memasukkan yang telah mereka baca kedalam inti pengetahuannya (core knowledge) (Pennsylvania Departmen of Education, 2016).

All America Reads (2003) menyajikan bukti seorang pembaca remaja mahir dari tingkat 6-12 yang telah melakukan kegiatan membaca dalam 3 tahapan membaca. Pada tahap sebelum mebaca is menetapkan tujuan, membentuk kerangka konseptual untuk mengingat-ingat jenis-jenis teks secara terus menerus, dan mengaktifkan latar belakang pengetahuan terkait dengan topik bacaan. Pada tahap sewaktu membaca ia membaca secara aktif untuk suatu tujuan, memonitor pemahaman, membedakan antara gagasan yang penting dengan yang kurang penting, menggunakan sebagai senjata strategistrategi yang sesuai, menarik hubungan-hubungan dengan teks/dunia luar/diri, mengidentifikasi kosakata baru dengan penanda konteks, membaca secara fleksibel dengan menggunakan berbagai strategi seperti scaning dan skiming, berinteraksi dengan teks dengan menanya, memprediksi, menafsirkan berbagai simbol lintas bidang permasalahan, memanfaatkan keterampilan-keterampilan membaca kritis, seperti mengevaluasi, menafsirkan dan menganalisis, mengenal perbedaan antara fakta dan opini, dan mengenal kekeliruan-kekeliruan logis. Pada tahap setelah membaca, ia mensintesakan informasi dari berbagai sumber untuk mengembangkan pemahaman dan memikirkan langkah-langkah selanjutnya dengan bertanya pada diri sendiri "Apa lagi yang perlu saya ketahui?", merangkum teks yang telah dibaca dengan menceritakan kembali alur atau gagasan utamanya, mengevaluasi gagasan.

Salah satu upaya untuk meningkatkan kualitas strtegi membaca ditawarkan oleh Greece Central School District, khususnya apabila menghadapi teks yang sulit dan kompleks, atau bila tidak dapat membaca secara efektif dalam situasi dan kondisi normal. Kita dapat memperbaiki cara membaca kita dengan menjadi lebih bertujuan dalam melakukan pendekatan terhadap kegiatan membaca melalui proses 3 tahap: (a) perencanaan membaca, (b) pembacaan, dan (c) refleksi bacaan. Perencnaan membaca akan membantu pembacaan kita fokus. Setelah fokus membaca dicapai, proses 
selanjutnya yaitu melakukan pembacaan.Tidak ada pendekatan khusus, tetapi ada prinsip-prinsip yang bermanfaat sebagai petunjuk, yaitu temukan awal penulis mengemukakan argumentasinya, yang biasanya pada paragraf pertama atau kedua. Pada tahap refleksi, pikirkan apa yang telah kita baca, misalkan apakah ada pertanyaanpertanyaan mengenai arti teks yang tidak terjawab, apakah kita mampu menghubungkan antara teks dan materi lain yang telah kita baca, dan terakhir, gunakan catatan dan refleksi kita untuk merespon pertanyaan-pertanyaan yang telah diajukan.

Kemampuan membaca seseorang dipengaruhi oleh kualitas strategi yang diterapkan dalam proses membaca. Sementara itu, kemampuan membaca diyakini berpengaruh terhadap kemampuan lain, misalnya kemampuan menulis dan kemampuan mendengarkan. Krashen \& Lee (2004) menemukan kemampuan membaca memberi sumbangan terhadap kemampuan menulis karena membaca memberi penulis pengetahuan mengenai bahasa menulis, tata bahasa, kosakata, dan gaya menulis yang digunakan penulis (Krashen \& Lee, 2004). Disimpulkan pula oleh Diakidoy dkk., (2004) bahwa ada hubungan antara kemampuan membaca dan kemampuan mendengarkan.

Hasil penelitian mengenai hubungan antara strategi membaca dan pemahaman membaca menunjukkan bahwa penerapan strategi membaca berpengaruh siginifikan terhadap pemahaman membaca pembelajar bahasa Inggri sebagai bahasa asing (EFL learners) (Karizak and Khojasteh, 2016). Hasil penelitian sejenis dikemukakan oleh Alharbi (2015), yang menunjukkan bahwa strategi membaca keras (oral reading) dan membaca dalam hati (silent reading) tidak berbeda secara signifikan terhadap pemahaman membaca pembelajar bahasa Inggris sebagai bahasa asing (EFL learners). Perbedaan penelitian ini dengan penelitian yang dilakukan oleh para pakar di atas terletak pada variabel terikat yang digunakan. Pada penelitian ini variabel terikatnya adalah pretasi akademik, yang mencakup tidak hanya kemampuan berbahasa tertentu seperti kemampuan menulis dan mendengarkan, tetapi kemampuan secara umum, yang direpresentasikan dengan IPK. Perbedaan lain adalah penggunaan strategi membaca tidak diklasifiksi seperti dalam penelitian ini, yaitu menajdi baik, cukup, dan kurang.

Rumusan masalah dalam penelitian ini dinyatakan dalam pertanyaan penelitian, yakni: Apakah kualitas strategi membaca berpengaruh terhadap prestasi akademik? Tujuan penelitian ini adalah mengkaji pengaruh kualitas strategi membaca terhadap prestasi akademik. Hipotesis penelitian yang diajukan adalah kualitas strategi membaca berpengaruh terhadap prestasi akademik mahasiswa.

Dengan mengetahui kualitas strategi membaca mahasiswa, program studi dapat mengambil kebijakan yang tepat sehingga pada akhirnya mahasiswa dapat menjadi pembaca yang mandiri, efektif, efisien, dan strategis seperti yang diharapkan.

\section{METODE}

Penelitian ini menggunakan desain campuran kualitatif - kuantitatif karena cara pengumpulan datanya non-eksperimental, jenis datanya kualitatif dan kauntitatif, sedangkan analisis datanya menggunakan teknik statistika. Desain penelitian seperti ini oleh Grotjahn (dalam Nunan, 1992) disebut exploratory-qualitative-statistical.

Variabel yang diteliti adalah kualitas strategi membaca yang diterapkan oleh mahasiswa, baik dalam perkuliahan Reading maupun kegiatan membaca secara umum. Strategi membaca yang diteliti adalah strategi membaca pada tahap sebelum, sewaktu, dan setelah membaca. Variabel penelitian kedua adalah prestasi akademik mahasiswa yang direpresentasikan dengan indeks prestasi kumulatif (IPK).

Dalam penelitian ini dikaji pengaruh strategi membaca terhadap prestasi akademik. Dengan demikian, variabel prestasi akademik berlaku sebagai variabel terikat, 
sedangkan kualitas strategi membaca berlaku sebagai variabel bebas: dikaji apakah kualitas strategi membaca, yang dikategori menjadi 3, berpengaruh terhadap prestasi akademik, yang diwakili oleh 2 kelompok, yaitu kelompok atas dan kelompok bawah.

Subjek dalam penelitian ini adalah 104 mahasiswa PBI UMK yang dipilih secara acak, yang terdiri dari semester II sebanyak 27, semester IV sebanyak 28, semester VI sebanyak 28, dan semester VIII ke atas sebanyak 21.

Data dikumpulkan melalui angket tertutup yang terdiri dari 20 pertanyaan positif. Pada setiap pertanyaan terdapat 4 pilihan jawaban, a, b, c, dan d, yang masing-masing bermakna dan diberi bobot seperti tergambar dalam Tabel 1.

Tabel 1. Pembobotan Pilihan Jawaban

\begin{tabular}{ll}
\hline Pilihan Jawaban & Bobot \\
\hline a. selalu & 4 \\
\hline b. sering & 3 \\
\hline c. kadang-kadang & 2 \\
\hline d. tidak pernah & 1 \\
\hline
\end{tabular}

Pada bagian identitas dalam angket, responden diminta untuk menuliskan nama, semester, jenis kelamin, dan IPK. IPK seluruh responden diurutkan dari yang tertinggi sampai yang terendah dan selanjutnya dikelompokkan menjadi 2 sehingga diperoleh 2 kelompok responden/mahasiswa berdasarkan prestasi akademik mereka, yaitu kelompok atas dan kelompok bawah, yang masing-masing berjumlah 52 .

Setelah dilakukan penghitungan terhadap pilihan jawaban untuk setiap pertanyaan dari seluruh responden, dilakukan penghitungan untuk menentukan kualitas strategi membaca mahasiswa dari setiap tahap membaca dengan berpedoman pada Tabel 2 .

Tabel 2. Kriteria Kualitas Strategi Membaca

\begin{tabular}{ll}
\hline Rentang Nilai & Kualitas Strategi \\
\hline $3,00-4,00$ & Baik \\
\hline $1,90-2,90$ & Cukup Baik \\
\hline$<1,90$ & Kurang Baik \\
\hline
\end{tabular}

Untuk mengkaji hubungan antara kualitas strategi membaca dan prestasi akademik, yaitu apakah kualitas strategi membaca berpengaruh terhadap prestasi akademik, digunakan teknik statistika non-parametrik Uji Kuadrat Chi Ketidaktergantungan (Chi Square Test of Independence). Rumus yang digunakan untuk menghitung harga kuadrat chi $\left(X^{2}\right.$ hitung) adalah:

$$
\sum\left[\frac{(f o-f h)^{2}}{f h}\right]
$$

Uji hipótesis dilakukan dengan model 5 langkah yang dikembangkan oleh Healy (2009), dengan kriteria hasil pengujian sebagai berikut.

Kriteria hasil pengujian

Pada taraf signifikansi $(\alpha) 5 \%$ dan derajat kebebasan $($ baris -1$)($ kolom -1$)=(3-$ 1) $(2-1)=2$ : 1 . Tolak H0 dan terima Ha bila X2(hitung) jatuh di daerah kritis: 
X2(hitung) > X2 (tabel).

Artinya, ada hubungan antara kualitas strategi membaca dan prestasi akademik: kualitas strategi membaca berpengaruh terhadap prestasi akademik.

2.Terima $\mathrm{H}_{0}$ dan tolak $\mathrm{H}_{\mathrm{a}}$ bila $X^{2}$ (hitung) tidak jatuh di daerah kritis: $X^{2}$ (hitung) $<X^{2}$ (tabel).

Artinya, tidak ada hubungan antara kualitas strategi membaca dan prestasi akademik:

kualitas strategi membaca tidak berpengaruh terhadap prestasi akademik.

\section{HASIL}

Bagian ini berisi uraian mengenai kualitas strategi membaca dan hubungan antara kualitas strategi membaca dan prestasi akademik. Bagian ini juga dilengkapi dengan pengujian hipotesis.

\section{Kualitas Strategi Membaca}

Tabel 3 berikut ini adalah data kualitas strategi membaca mahasiswa PBI UMK.

Tabel 3. Kualitas Strategi Membaca Mahasiswa PBI UMK

\begin{tabular}{ccccccccc}
\hline \multirow{2}{*}{ Semester } & \multicolumn{9}{c}{ Tahap Membaca } & \multirow{2}{*}{ Total } \\
\cline { 2 - 6 } & \multicolumn{1}{c}{ Sebelum } & \multicolumn{2}{c}{ Selama } & \multicolumn{2}{c}{ Setelah } & & Rata- \\
\cline { 2 - 6 } & $\begin{array}{c}\text { Rata- } \\
\text { rata }\end{array}$ & Kualitas & $\begin{array}{c}\text { Kualitas } \\
\text { rata }\end{array}$ & $\begin{array}{c}\text { Rata- } \\
\text { rata }\end{array}$ & Kualitas & $\begin{array}{c}\text { Rata- } \\
\text { rata }\end{array}$ & Kualitas \\
\hline II & 3.07 & Baik & 2.73 & $\begin{array}{c}\text { Cukup } \\
\text { Baik }\end{array}$ & 2.33 & $\begin{array}{c}\text { Cukup } \\
\text { Baik }\end{array}$ & 2.81 & $\begin{array}{c}\text { Cukup } \\
\text { Baik }\end{array}$ \\
\hline IV & 2.88 & $\begin{array}{c}\text { Cukup } \\
\text { Baik }\end{array}$ & 2.68 & $\begin{array}{c}\text { Cukup } \\
\text { Baik }\end{array}$ & 2.51 & $\begin{array}{c}\text { Cukup } \\
\text { Baik }\end{array}$ & 2.69 & $\begin{array}{c}\text { Cukup } \\
\text { Baik }\end{array}$ \\
\hline VI & 3.02 & Baik & 2.90 & $\begin{array}{c}\text { Cukup } \\
\text { Baik }\end{array}$ & 2.50 & $\begin{array}{c}\text { Cukup } \\
\text { Baik }\end{array}$ & 2.84 & $\begin{array}{c}\text { Cukup } \\
\text { Baik }\end{array}$ \\
\hline VIII & 3.08 & Baik & 2.84 & $\begin{array}{c}\text { Cukup } \\
\text { Baik }\end{array}$ & 2.50 & $\begin{array}{c}\text { Cukup } \\
\text { Baik }\end{array}$ & 2.81 & $\begin{array}{c}\text { Cukup } \\
\text { Baik }\end{array}$ \\
\hline Rata-rata & 3.01 & Baik & 2.79 & $\begin{array}{c}\text { Cukup } \\
\text { Baik }\end{array}$ & 2.46 & $\begin{array}{c}\text { Cukup } \\
\text { Baik }\end{array}$ & 2.79 & $\begin{array}{c}\text { Cukup } \\
\text { Baik }\end{array}$ \\
\hline
\end{tabular}

Dari Tabel 3 dapat dilihat bahwa nilai rata-rata kualitas strategi membaca mahasiswa PBI UMK secara keseluruhan adalah 2,79 sehingga termasuk kategori "cukup baik". Sementara itu, untuk setiap tahapan membaca, hanya pada tahap sebelum membaca kualitas strategi membaca mahasiswa berada pada posisi "baik" dengan nilai 3,01, sedangkan untuk tahap selama dan setelah membaca kualitasnya "cukup baik".

\section{Hubungan antara Kualitas Strategi Membaca dan Prestasi Akademik}

Distribusi frekuensi kualitas strategi membaca berdasarkan prestasi akademik tercantum dalam Tabel 4. 
Tabel 4. Distribusi Frekuensi Kualitas Strategi Membaca Berdasarkan Prestasi Akademik (IPK)

\begin{tabular}{ccccccc}
\hline \multirow{2}{*}{$\begin{array}{c}\text { Kualitas } \\
\text { Strategi Membaca }\end{array}$} & \multicolumn{2}{c}{ Kelompok Atas } & \multicolumn{2}{c}{ Kelompok Bawah } & \multicolumn{2}{c}{ Jumlah } \\
\cline { 2 - 7 } & $f$ & $\%$ & $f$ & $\%$ & $F$ & $\%$ \\
\hline Baik & 13 & 25.00 & 14 & 26.92 & 27 & 25.96 \\
\hline Cukup & 39 & 75.00 & 38 & 73.08 & 77 & 74.04 \\
\hline Kurang & 0 & 0.00 & 0 & 0.00 & 0 & 0.00 \\
\hline Jumlah & 52 & 100.00 & 52 & 100.00 & 104 & 100.00 \\
\hline
\end{tabular}

Dari Tabel 4 dilakukan penghitungan harga frekuensi harapan (fh), yang selanjutnya dilakukan penghitungan harga $\boldsymbol{X}^{2}$ dengan Tabel 5 .

Tabel 5. Penghitungan Harga Kuadrat Chi Kualitas Strategi Membaca Berdasarkan Prestasi Akademik (IPK)

\begin{tabular}{clccccc}
\hline Kelompok & $\begin{array}{c}\text { Kualitas } \\
\text { Strategi } \\
\text { Membaca }\end{array}$ & $f o$ & $f h$ & $f o-f h$ & $\begin{array}{l}(f o- \\
f h)^{2}\end{array}$ & $\sum\left[\frac{(f o-f h)^{2}}{f h}\right]$ \\
\hline Atas & Baik & 13 & 13.5 & -0.50 & 0.250 & 0.019 \\
\hline & Cukup Baik & 39 & 38.5 & 0.50 & 0.250 & 0.006 \\
\hline & Kurang baik & 0 & 0 & 0.00 & 0.000 & 0.000 \\
\hline
\end{tabular}

\begin{tabular}{clccccc}
\hline Bawah & Baik & 14 & 13.5 & 0.50 & 0.250 & 0.019 \\
\hline & Cukup Baik & 38 & 38.5 & -0.50 & 0.250 & 0.006 \\
\hline Kurang baik & 0 & 0 & 0.00 & 0.000 & 0.000 \\
\hline & & & & $\boldsymbol{X}^{2}=$ & 0.050 \\
\hline
\end{tabular}

\section{Pengujian Hipotesis}

Langkah 1. Membuat asumsi-asummsi dan memenuhi persayaratan-persyaratan pengujian:

a. Sampel ditarik secara acak

b. Tingkatan data nominal

Langkah 2. Menyatakan hipótesis nol dalam pengujian:

$\mathrm{H}_{0}$ : kualitas strategi membaca tidak berpengaruh terhadap prestasi akademik

$\left(\mathrm{H}_{\mathrm{a}}\right.$ : kualitas strategi membaca berpengaruh terhadap prestasi akademik)

Langkah 3. Memilih distribusi sampling yang digunakan dan menentukan harga kritisnya: 


$\begin{array}{lll}\text { b. } \text { Alfa }(\alpha) & = & 0,05(5 \%) \\ \text { c. Derajat kebebasan } & = & 2 \\ \text { d. Harga kritis } X^{2} & = & 5,991\end{array}$

Langkah 4. Menghitung harga statistik kuadrat chi dengan rumus pada poin 3):

Dari penghitungan dengan Tabel 5 diperoleh harga $X^{2}=0.050$

Langkah 5. Membuat keputusan dan menafsirkan hasil pengujian:

\section{Hasil Pengujian:}

Pada taraf signifikansi $(\alpha) 5 \%$ dan derajat kebebasan 2 hipotesis nol gagal ditolak atau hipotesis nol diterima sehingga hipotesis penelitian ditolak karena harga $X^{2}$ tidak jatuh di daerah kritis atau $X^{2}<X^{2}$ tabel $(0,050<5,911)$. Dengan demikian, tidak ada hubungan yang sinifikan antara kualitas strategi membaca dan prestasi akademik mahasiswa. Dengan kata lain, kualitas strategi membaca tidak tidak berpengaruh terhadap prestasi akademik.

\section{PEMBAHASAN}

\section{Kualitas Strategi Membaca}

Membaca adalah suatu proses yang dilakukan serta dipergunakan oleh pembaca untuk memperoleh pesan yang hendak disampaikan oleh penulis melalui media katakata/bahasa tulis (Tarigan, 1986:7). Keberhasilan sebuah kegiatan membaca ditandai dengan pemahaman yang baik dan tepat dari sebuah teks. Untuk mencapai hal tersebut diperlukan strategi membaca yang berkualitas sebelum, selama dan setelah proses membaca; bukan suatu proses yang hanya menuntut agar kelompok kata yang merupakan suatu kesatuan akan terlihat dalam suatu pandangan sekilas, dan agar makna kata-kata secara individual akan dapat diketahui. Bila proses ini gagal, maka pesan yang tersurat dan yang tersirat tidak akan diperoleh atau dipahami, dan proses membaca tidak menemukan tujuannya.

Membaca pemahaman adalah kegiatan yang bertujuan untuk mendapatkan informasi yang mendalam serta pemahaman tentang teks yang dibaca. Membaca pemahaman merupakan pemahaman arti atau maksud dalam suatu bacaan melalui tulisan. Definisi ini sangat menekankan dua hal yang pokok dalam membaca, yaitu bahasa itu sendiri dan simbol grafik tulisan yang menyajikan informasi yang berwujud bacaan (Lado dalam Nurhadi, 1987:222). Kegiatan membaca yang efektif dan efisien merupakan pondasi dari yang baik untu keberhasilan proses belajar mengajar di perguruan tinggi bagi para mahasiswa. Kemampuan membaca merupakan modal utama dalam meraih prestasi akademik. Kajian tentang strategi membaca ini sangat berguna untuk penigkatan prestasi akademik secara umum.

Dalam pre-reading strategi membaca yang umum dipakai adalah membaca judul bacaan dan kemudian memprediksi hu-bungannya dengan isi bacaan. Strategi yang paling jarang digunakan yaitu membaca kalimat pertama dari masing-masing paragraf untuk mencari pikiran utama bacaan. Tahap membaca dilakukan dengan memikirkan pengetahuan yang telah dimiliki dan menghubungkannya dengan tema bacaan, serta membaca sekilas untuk mendapatkan gambaran umum bacaan. Pembaca akan tergantung pada pengaktifan skemata untuk membantu memahami bacaan.

Selama whilst-reading ditemukan bahwa pembaca telah terbiasa menggunakan hampir semua strategi membaca. Strategi yang paling umum digunakan adalah mencari makna kata penting di kamus, sedangkan yang paling jarang digunakan adalah membaca tanpa mencari arti setiap kata sulit yang ditemui dalam kamus. Di samping itu, menebak 
arti kata dari kategori tata bahasa dan memperhatikan kata atau frasa tertentu yang menunjukkan struktur bacaan tidak pernah digunakan oleh pembaca. Mereka mengalami ketidakefektifan dalam penggunaan strategi-strategi tersebut mungkin dikarenakan oleh kekurang pahaman pembaca terhadap kategori kata, kata sambung, dan penanda transisi dan sebagainya yang menunjukkan cara penulis menyusun ide-idenya dalam bacaan, serta mungkin karena keengganan siswa itu sendiri untuk menggunakan strategi tersebut ketika membaca.

Untuk dapat melihat apakah kualitas strategi membaca yang diterapkan oleh mahasiswa PBI UMK berpengaruh terhadap prestasi akademik mereka, terlebih dahulu diindentifikasikualitas strategi membaca mahasiswa. Hasil kajian membuktikan bahwa rata-rata kuaitas strategi membaca mahasiswa prodi PBI secara keselurahan adalah 2,79 sehingga masuk kategori cukup baik. Sementara untuk setiap tahapan membaca, hanya pada tahap Sebelum membaca kualitas strategi membaca mahasiswa berada pada posisi baik (nilai 3,01), sedangkan untuk tahap selama dan setelah membaca kualitasnya cukup baik.

Hasil penelitian ini mengisyaratkan bahwa kegiatan sebelum membaca tidak bertentangan dengan terori membaca yang telah disebutkan dalam kajian pustaka. Hal baru dan spesifik yang muncul dalam kajian ini adalah bahwa tidak semua tahapan membaca mahasiswa PBI mempunyai kualitas stretegi yang baik. Ternyata hanya pada tahap pre-reading strategi mahasiswa itu masuk dalam kategori baik. Penelitian selanjutnya perlu dilakukan untuk mencari kualitas membaca dalam setiap tahap yang lebih rinci dan bukan hanya kegiatan membaca keseluruahan sehingga kajian menjadi lebih rinci dan spesifik. Ada kemungkinan perhatian mahasiswa berada dalam kondisi yang masih baik pada awal proses membaca sehingga kualitas strategi sebelum membaca dapat muncul. Penurunan perhatian dapat saja terjadi pada tahap selama dan setelah membaca sehingga kualitas strateginya menurun.

Berdasarkan Tabel 5, secara umum kualitas strategi membaca mahasiswa PBI UMK termasuk kategori "cukup baik". Namun demikian, bila diamati lebih detail, pada tahap sebelum membaca hanya semester IV yang kualitasnya "cukup baik". Sementara itu, kualitas ketiga angkatan yang lain termasuk kategori "baik". Jadi, dapat ditafsirkan secara umum mahasiswa mempersiapkan diri dengan baik sebelum aktivitas membaca mereka dimulai.

Meskipun kualitas strategi membaca mahasiwa pada tahap selama dan sesudah membaca berkategori sama, yaitu "cukup baik", tetapi nilai-nilainya cenderung lebih besar tahap selama membaca. Fakta tersebut menunjukkan bahwa konsentrasi mahasiswa pada tahap selama membaca lebih baik dibandingkan dengan pada tahap setelah membaca.

\section{Hubungan antara Kualitas Strategi Membaca dan Prestasi Akademik}

Sifat hubungan antara variabel kualitas strategi membaca dan prestasi akademik dapat timbal-balik, yaitu strategi membaca dapat berpengaruh terhadap prestasi akademik, ataupun sebaliknya prestasi akademik berpengaruh terhadap strategi membaca. Akan tetapi, penelitian ini mengkaji apakah kualitas strategi membaca yang diterapkan oleh mahasiswa PBI UMK berpengaruh terhadap prestasi akademik mereka. Berdasarkan prestasi akademik, mahasiswa dibedakan antara kelompok atas dan kelompok bawah. Secara empirik pada taraf signifikasi 5\% dan derajat kebebasan 2, hipotesis nol gagal ditolak, sehingga hipotesis penelitian ditolak. Dengan kata lain, kualitas strategi membaca tidak berpengaruh pada tingkat prestasi akademiknya. Hal ini terjadi kemungkinan karena kualitas strategi membaca kedua kelompok dalam kategori yang sama, yaitu "cukup baik" dengan selisih yang cukup kecil, yaitu 0,03 (2,80 
berbanding 2,77). Fakta tersebut nampaknya kurang sejalan dengan teori dan harapan umum bahwa kualitas strategi membaca yang baik akan menunjukkan prestasi akademik yang baik pula. Hal ini mengingat bahwa kemampuan membaca akan menyumbang pada prestasi akademik dan strategi membaca yang baik akan menyumbang pada kemampuan membaca yang baik. Penelitian ini justru menunjukkan bahwa tidak ada hubungan antara kualitas strategi membaca dan prestasi akdemik mahasiswa. Prestasi akademik mahasiswa juga banyak melibatkan mata kuliah di luar membaca. Namun, hal ini bisa dijelaskan bahwa secara umum prestasi akademik mahasiswa memang dipengaruhi oleh banyak faktor di luar kemampuan membaca. Pengajaran membaca ke depan di program studi ini harus lebih ditingkatkan kualitasnya, di antaranya dengan lebih baik mengenalkan berbagai strategi membaca yang lebih lengkap. Hal ini diharapkan supaya kualitas strategi membaca mahasiswa bisa berkontribusi nyata terhadap presetasi akademik mahasiswa.

Bahwa tidak ada hubungan antara kualitas strategi membaca dengan prestasi akademik karena berdasarkan data yang ada frekuensi mahasiswa kelompok atas dan kelompok bawah yang kualitas strategi membacanya baik, cukup dan kurang relatif sama (Tabel 4). Penjelasan lain adalah bahwa kualitas strategi membaca keseluruhan mahasiswa pada setiap tahap membaca juga relatif sama (Tabel 3). Dengan kata lain, mahasiswa PBI UMK yang bertindak sebagai subjek penelitian ini bersifat homogen. Penemuan senada dikemukakan oleh Bolanos (2012) bahwa tidak ada perbedaan yang signifikan dalam hal pemahman membaca antara pembaca teks tercetak (print) dan pembaca hypertexts, yang berarti bahwa modus penyampaian teks tidak berpengaruh signifikan terhadap tingkat dan kualitas pemahaman membaca.

\section{SIMPULAN}

Hasil penelitian menunjukkan bahwa tidak ada hubungan antara prestasi akademik dengan kualitas strategi membaca: kualitas strategi membaca tidak berpengaruh terhadap prestasi akademik mahasiswa. Kualitas strategi membaca mahasiswa Prodi PBI FKIP UMK secara keseluruhan termasuk kategori "cukup baik". Sementara itu, untuk setiap tahapan membaca, hanya pada tahap sebelum membaca saja kualitas strategi membaca mahasiswa berada pada posisi "baik", sedangkan untuk tahap selama dan setelah membaca kualitasnya "cukup baik".

\section{DAFTAR PUSTAKA}

All America Reads. (2003). Diunduh 21 Februari 2016 dari: info@ allamericareads. org.

Alharbi, M. A. (2015). Reading strtegies, learning styles and reading comprehension: A Correlation Study. Journal of Language Teaching and Research. 6(6), 1257-1268.

Barnett, M. A. (1988). Teaching through context: how real and perceived strategy use affect 12 comprehension. The Modern Language Journal,72(2), 150-162. http://onlinelibrary.wiley.com/doi/10.1111/j.1540-4781.1988.tb04177.x/ abstract.

Chamot, A.U. (2005). Language learning strategy instruction. Jurnal Annual Review of Applied Linguistics, (25), 112-130.

Cohen, A. D. (1998). Second language learning and language use strategies: defining terms. Dalam andrew d. Cohen: strategies in learning and using a second language (pp. 3-23). London: Longman

Diakidoy, I-A.; Stylianou, P.; Karefillidou, C.; Papageorgiou, P. (2004). The relationship between listening and reading comprehension of different types of 
text at increasing grade levels. Jurnal Reading Psychology an international quarterly, 26(1), 55-80.

Foertsch. (1998). Basic definition of reading. Diunduh 7 September 2016 dari: http://www.ncrel.org

Healey, J. F. (2009). Statistics: a tool for social research eighth edition. Belmont, CA: Wardsworth Cengage Learning.

Hosenfield, C. (1977). A preliminary investigation of the reading strategies of successful and unsuccessful language learners. Jurnal System, 5 (2), 110-123.

Karizak, A. F. and Khojasteh, L. (2016). The effect of three kinds of reading strategies on EFL learners' reading comphehension and gender difference using think-aloud protocol. International Journal of Applied Linguistics \& English Literature, 5(5), 6-14.

Kissau, S. (2013). Reading comprehension strategies: an international comparison of teacher preferences. Jurnal Research in Comparative and International Education, 8(4). 437-454.

Krashen, S. and Lee, S. (2004). Competence in foreign language writing: progress and lacunae. Jurnal on CUE, 12(2), 10-14.

Nunan, D. (1992). Research methods in language learning. New York: Cambridge University Press.

Nurhadi. (1987). Membaca cepat dan efektif. Bandung: CV. Sinar Baru.

Palincsar, A. S. and Brown, A. L. (1984). Reciprocal teaching of comprehensionfostering and comprehension-monitoring activities. Jurnal Cognition and Instruction, I (2), 117-175.

Pearson, P., \& Gallagher, M. (1983). The instruction of reading comprehension. Jurnal Contemporary Educational Psychology,( 8), 317- 344.

Pennsylvania Departmen of Education. (2016). Before-during-after reading strategies. Diunduh 21 September 2016 dari: http://www.education.pa.gov/Teachers\%20$\% 20$ Administrators/Curriculum/Pages/Before-During-After-Reading-

Strategies.aspx\#tab-1. 